\title{
Vitamin Requirements of Root Nodule Bacteria
}

\author{
BY P. H. GRAHAM \\ Institute of Agriculture, University of Western Australia, Nedlands, \\ Western Australia
}

(Received 8 May 1962)

\begin{abstract}
SUMMARY
The vitamin requirements of 63 strains of Rhizobium and 18 of Agrobacterium were examined. $\boldsymbol{R}$. trifolii, $\boldsymbol{R}$. leguminosarum and $\boldsymbol{R}$. phaseoli responded in most cases to thiamine, biotin, and calcium pantothenate. Strains of $\boldsymbol{R}$. meliloti and the slow-growing rhizobia sometimes responded to biotin, but not to the other vitamins. An unknown growth factor, active for the slow-growing rhizobia, was detected. Three strains of Agrobacterium required thiamine.
\end{abstract}

\section{INTRODUCTION}

Species of root nodule bacteria differ in their vitamin requirements. Biotin is essential for growth of strains of Rhizobium leguminosarum, $R$. trifolii, $R$. phaseoli, R. meliloti and $R$. lupini (West \& Wilson, 1939 $a, b, 1940$ ). In some instances it is required only to initiate growth (Allen \& Allen, 1950). According to Jordan (1952), some strains of $\boldsymbol{R}$. meliloti require neither biotin nor any other of the $\mathbf{B}$ group of vitamins. Biotin is apparently not required by cowpea or soybean rhizobia or by the common nodule contaminant Agrobacterium radiobacter (West \& Wilson, $1939 a$, 1940). Thiamine and pantothenic acid stimulate growth of some strains of $R$. trifolii (West \& Wilson, $1939 a$; Lilly \& Leonian, 1945; Ljunggren, 1961), but in others they are either not required for growth (McBurney, Bollen \& Williams, 1935; Jordan, 1952) or have not been tested (Allen \& Allen, 1950). Synthesis of large amounts of vitamin $B_{12}$ by the rhizobia (Burton \& Lochhead, 1952; Levin, Funk \& Tendler, 1954) has been considered in relation to leghaemoglobin production in the nodule (Levin et al. 1954). A cobalt requirement has been established for both rhizobial growth] (Lowe, Evans \& Shaukat, 1960) and symbiotic fixation (Shaukat \& Evans, 1961).

The experiments reported here form part of an investigation of rhizobial taxonomy and were suggested by Dr C. A. Parker and Mr A. E. Oakley following their development of a defined growth medium for strains of Rhizobium trifolii.

\section{METHODS}

Organisms. The organisms used in routine work were maintained on yeast extract mannitol (YM) agar and were subcultured at monthly intervals. They were preserved by the lyophilization method described by Annear (1956) and the ampoules were stored at $4^{\circ}$.

Media. The defined basal medium used throughout contained (g./l. distilled water): $\mathrm{MgSO}_{4} .7 \mathrm{H}_{2} \mathrm{O}, 0.25 ; \mathrm{CaSO}_{4} .2 \mathrm{H}_{2} \mathrm{O}, 0.03 ; \mathrm{KH}_{2} \mathrm{PO}_{4}, 0.55 ; \mathrm{CuSO}_{4} .5 \mathrm{H}_{2} \mathrm{O}$, 
$0.00008 ; \mathrm{ZnSO}_{4} .7 \mathrm{H}_{2} \mathrm{O}, 0.00016 ; \mathrm{FeSO}_{4} .7 \mathrm{H}_{2} \mathrm{O}, 0.0035 ; \mathrm{NaCl}, 0.25 ; \mathrm{Na}_{2} \mathrm{HPO}_{4} \cdot 12 \mathrm{H}_{2} \mathrm{O}$, $1.20 ; \mathrm{MnSO}_{4} .4 \mathrm{H}_{2} \mathrm{O}, 0.0004 ; \mathrm{H}_{8} \mathrm{BO}_{3}, 0.0005$; urea, 0.5 ; glucose, 10.0 ; sucrose, 10.0 ; tyrosine, 0.015 ; aspartic acid, 0.015 ; lysine, 0.015 ; histidine, 0.015 ; glutamic acid-HCl, $0 \cdot 10$; arginine, $0 \cdot 015$. The medium (minus the phosphates) was sterilized by autoclaving for $35 \mathrm{~min}$. at 5 p.s.i. Solutions and the phosphates were sterilized separately and added before use.

This medium, with thiamine- $\mathrm{HCl}(0.004 \mathrm{~g}$.), calcium pantothenate $(0.004 \mathrm{~g}$.$) and$ biotin (0.001 $\mathrm{mg}$.) per litre added, had previously been developed for two strains of Rhizobium trifolii. It supported growth to about $2 \times 10^{10}$ organisms/ml. (Dr Parker and Mr Oakley, personal communication). In the present work it was used either as a broth or solidified with $1.5 \%$ agar previously washed for 3 weeks in repeated changes of distilled water.

Experimental procedure. Ten vitamins were tested. Requirements for thiamine, calcium pantothenate, nicotinic acid, riboflavin, inositol, folic acid, $p$-aminobenzoic acid, vitamin $B_{12}$ and pyridoxin were studied by the agar disk method described by Ford \& Hutner (1957). Tubes of basal agar medium, each containing $25 \mathrm{ml}$., were liquefied by autoclaving, allowed to cool to $45^{\circ}$ and inoculated with a washed suspension of the appropriate organism; they were then agitated and poured. Sterile filter paper disks, each impregnated with $1 \mu \mathrm{g}$. of one of the vitamins under test, were placed on the agar plates. Plates were examined for the presence or absence of growth stimulation after 3 days at $28^{\circ}$. Biotin requirements could not be studied by this method because the biotin content of the agar, even after repeated washing, was sufficient to supply the needs of the organisms. Instead, liquid medium $(20 \mathrm{ml}$.) was used in $100 \mathrm{ml}$. Erlenmeyer flasks loosely plugged with biotin-free cotton wool and covered with a $50 \mathrm{ml}$. beaker. The flasks were then inoculated with a washed suspension as before; duplicate flasks and positive controls were used. They were incubated for 3 days at $28^{\circ}$ in a reciprocal shaking machine. After three successive transfers in the basal medium the flasks were examined for differences in growth.

\section{RESULTS}

There was no growth response by any of the cultures to nicotinic acid, pyridoxin, folic acid, $p$-aminobenzoic acid, inositol, vitamin $B_{12}$ or riboflavin. Strains of Rhizobium trifolii, $R$. leguminosarum and $\boldsymbol{R}$. phaseoli were alike in their requirement for biotin, thiamine and calcium pantothenate (Table 1). Of the 31 strains of these 3 species, 5 responded to both biotin and calcium pantothenate, 8 to thiamine and calcium pantothenate and 10 to thiamine, biotin and calcium pantothenate. Only 5 of the 31 strains did not require calcium pantothenate for maximum growth. In several instances both thiamine and calcium pantothenate were essential to initiate growth (Fig. 1). Biotin was also required by strains of $R$. lupini and $R$. meliloti, but the frequency with which it was required appeared to be much less than that suggested by earlier workers (Allen \& Allen, 1950). Thiamine was also required by one of 7 strains of $\boldsymbol{A}$. radiobacter and 2 of 11 strains of $A$. tumefaciens.

Strains of $\boldsymbol{R}$. lupini, $R$. japonicum and the cowpea rhizobia did not appear to require most of the vitamins studied in this work, although some unknown growth factor present in the yeast extract mannitol medium was absent from or deficient in the defined one. On transfer from YM agar medium these bacteria grew adequately 
Table 1. Vitamin requirements of Rhizobium and Agrobacterium species

Species

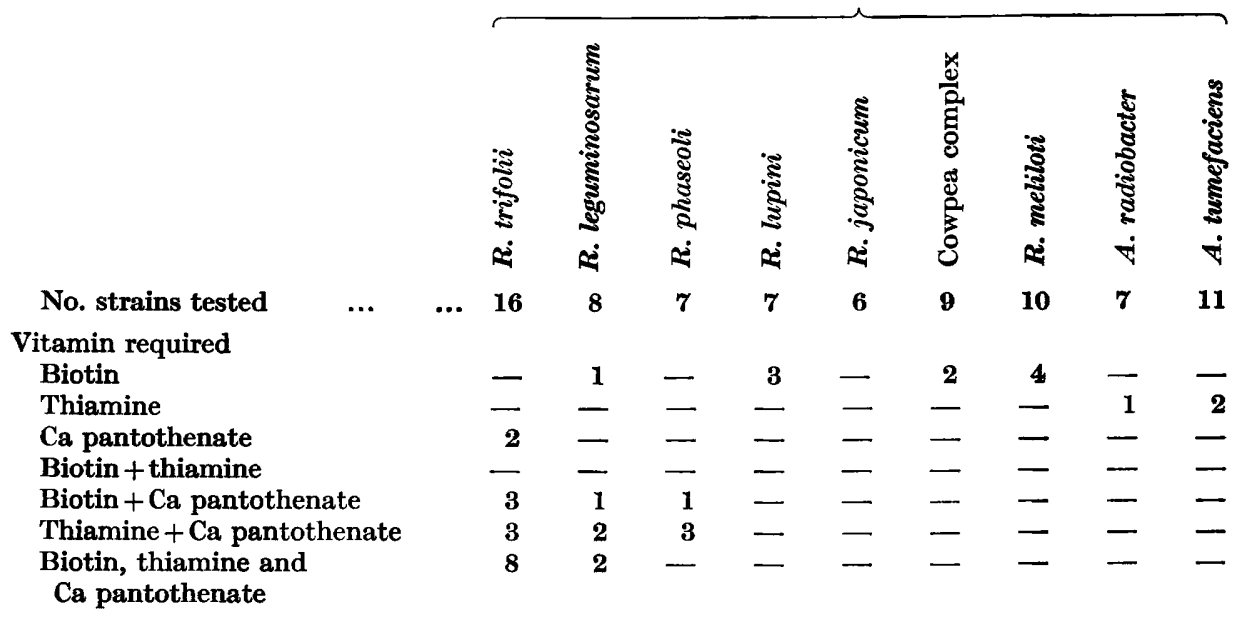

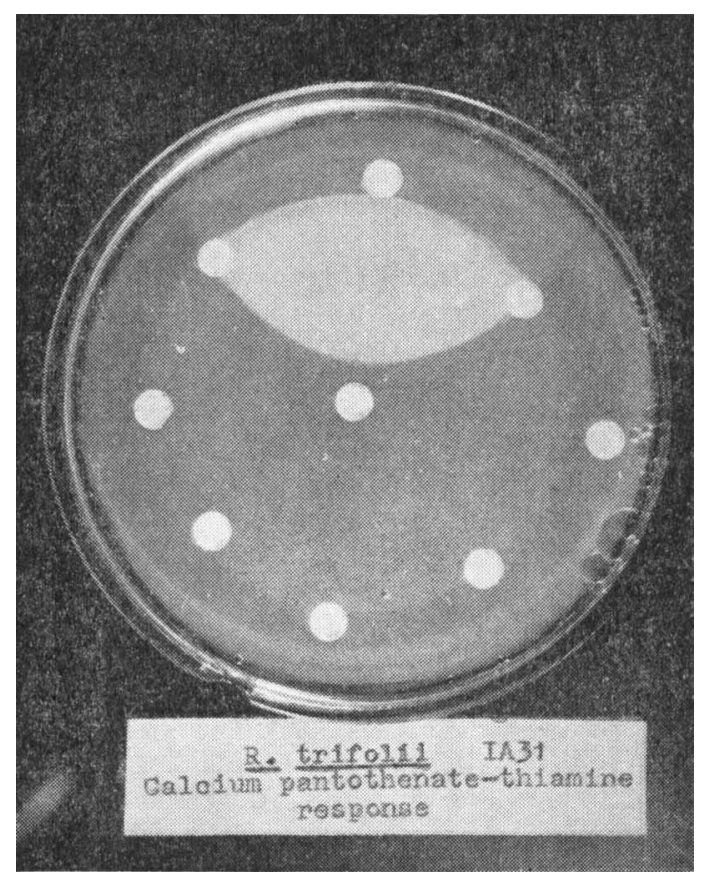

Fig. 1. Stimulation of the growth of Rhizobium trifolii strain $1 \mathrm{~A} 31$ by thiamine (central disk) and calcium pantothenate (centre, top). Note the absence of growth unless both vitamins are supplied.

at first but in subsequent transfers were much diminished in growth. Certain contaminating fungi overcame this deficiency, but adding L-glutamic acid, DL-tryptophan, DL-methionine, DL-valine, DL-phenylalanine, DL-threonine, L-citrulline, $\mathrm{L}$-cysteine $\mathrm{HCl}$, or $\mathrm{L}$-serine singly or in combination to the medium did not replace 
the requirement. Guanine, adenine, thymine, uracil, choline, thioctic acid and ascorbic acid were similarly inactive in making the defined medium like the YM agar.

Bergersen (1961) considered that near-maximal growth of root nodule bacteria can be achieved in a medium in which the only growth-promoting substances are thiamine, biotin and sodium glutamate. It would appear that at least two additional substances, namely, pantothenic acid and an unknown growth factor(s) are important in the nutrition of some of these bacteria. Bergersen's results indicate the necessity for using numerous representative strains in work on Rhizobium.

Vitamin and amino-acid requirements have been used in the separation and classification of various soil-borne bacteria (Lochhead, 1952) and in Adansonian classification (Sneath \& Cowan, 1958). The present results suggest that they could be equally valuable in classifying the root nodule bacteria. Further taxonomically useful characters are being sought.

The author thanks Dr C. A. Parker and Mr A. E. Oakley for their advice, and Miss R. Ambrose for technical assistance. The work was done during the tenure of the Bank of New South Wales Research Fellowship in Agriculture, and was financed from Wheat Industry Research Grants.

\section{REFERENCES}

Aluen, O. N. \& Aruen, E. K. (1950). Biochemical and symbiotic properties of the rhizobia. Bact. Rev. 14, 273.

Annear, D. I. (1956). Freeze drying. III. The preservation of bacteria. Labt. Pract. (1956), 102.

Bergersen, F. J. (1961). The growth of Rhizobium in synthetic media. Aust. J. biol. Sci. 14, 349.

Burton, M. O. \& Lochhead, A. G. (1952). Production of vitamin $B_{12}$ by Rhizobium species. Canad. J. Bot. 30, 521.

Ford, J. E. \& HUTNER, H. S. (1957). On the nature of the vitamin $B_{12}$ requirement in soil bacteria isolated by Lochhead and his coworkers. Canad. J. Microbiol. 3, 319.

Jordan, D. C. (1952). Studies on the legume root nodule bacteria. III. Growth factor requirements of effective, ineffective and parasitic strains. Canad. J. Bot. 30, 693.

Levin, A. P., Funk, H. B. \& Tendler, M. D. (1954). Vitamin $B_{12}$, rhizobia, and leguminous plants. Science, $120,784$.

LiLLy, V. G. \& LeONian, L. H. (1945). The interrelationships of iron and certain accessory growth factors in the growth of Rhizobium trifolii strain 205. J. Bact. 50, 393.

LJUNGGREN, H. (1961). Transfer of virulence in Rhizobium trifolii. Nature, Lond. 191, 623.

Lochenad, A. G. (1952). The nutritional classification of soil bacteria. Proc. Soc. appl. Bact. 15, 15.

Lowe, R. H., Evans, H. J. \& Shaukat, A. (1960). The effect of cobalt on the growth of Rhizobium japonicum. Biochem. Biophys. Res. Comm. 3, 675.

McBurney, C. H., Bollen, W. B. \& Williams, R. J. (1935). Pantothenic acid and the nodule bacteria-legume symbiosis. Proc. nat. Acad. Sci., Wash. 21, 301.

Shaukat, A. \& Evans, H. J. (1961). The essentiality of cobalt for soybean plants grown under symbiotic conditions. Proc. nat. Acad. Sci., Wash. 47, 24.

SNeath, P. H. A. \& Cowan, S. T. (1958). An electro-taxonomic survey of bacteria. J. gen. Microbiol. 19, 551.

WEST, P. M. \& WiLson, P. W. (1939a). Growth factor requirements of the root nodule bacteria. J. Bact. 37, 161.

WeST, P. M. \& WILson, P. W. (1939b). Effect of biotin concentrates on growth of Rhizobium and related species. $J$. Bact. $38,110$.

West, P. M. \& Wirson, P. W. (1940). Biotin as a growth stimulant for the root nodule bacteria. Enzymologia, 8, 152. 